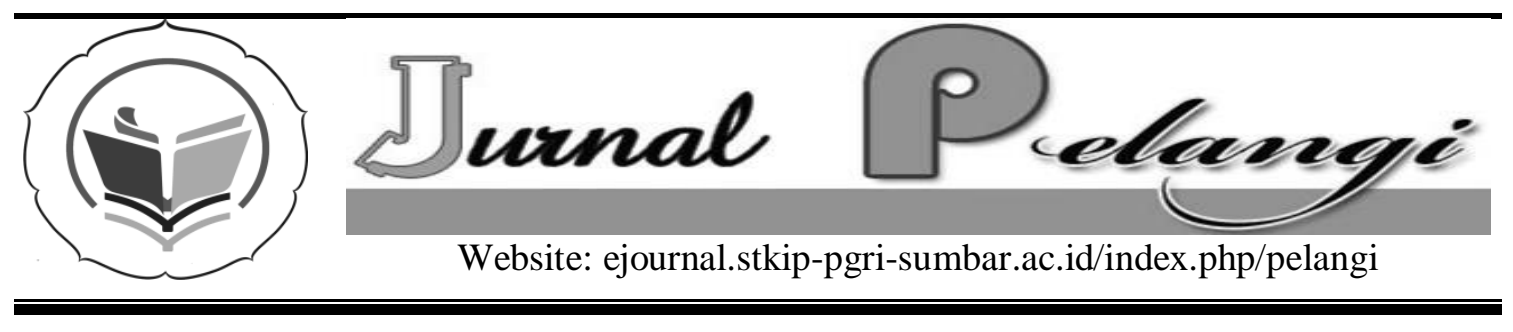

\title{
PENGARUH MODEL PEMBELAJARAN DISCOVERY LEARNING TERHADAP HASIL BELAJAR MATEMATIKA SISWA MAN MODEL KOTA JAMBI
}

\author{
Fitriyah, Ali Murtadlo, dan Rini Warti \\ IAIN STS Jambi \\ fitri.advan54@gmail.com
}

\section{INFO ARTIKEL}

Diterima:

23 Mei 2017

Direview:

9 Juni 2017

Disetujui:

3 September 2017

Kata Kunci:

hasil belajar, discovery learning, matematika

\section{Keywords:}

Learning Outcome, Discovery Learning, Mathematics

\begin{abstract}
Abstrak
Penelitian ini bertujuan untuk mengetahui perbedaan hasil belajar matematika antara yang menggunakan model pembelajaran discovery learning dengan yang menggunakan model pembelajaran konvensional pada siswa kelas XI IIS MAN Model Kota Jambi. Penelitian ini merupakan jenis penelitian eksperimen semu (quasi experiment). Populasi penelitian ini adalah kelas XI IIS yang terdiri dari 5 kelas berjumlah 182 orang. Sampel dalam penelitian ini adalah siswa kelas XI IIS.2 sebagai kelas eksperimen dan kelas XI IIS.3 sebagai kelas kontrol. Pengumpulan data dilakukan dengan menggunakan tes dan selanjutnya dianalisis dengan uji t-test. Hasil analisis menyimpulkan bahwa ada pengaruh penggunaan model discovery learning terhadap hasil belajar matematika pada pokok bahasan Matriks.
\end{abstract}

\section{Abstract}

This study aims to determine the difference between the results of learning mathematics learning using discovery learning model with which using conventional learning model in students of class XI IIS MAN Model Jambi City. This research is a kind of quasi experiment research. The population of this study is class XI IIS consisting of 5 classes amounted to 182 people. The sample in this research is student of class XI IIS.2 as experiment class and class XI IIS.3 as control class. The data were collected by using test and then analyzed by $t$-test. The results of the analysis conclude that there is an influence of the use of discovery learning model on the mathematics learning outcomes on Matrix subject matter. 


\section{PENDAHULUAN}

Pendidikan merupakan salah satu hal yang terpenting dalam kehidupan manusia, karena melalui pendidikan akan dapat menciptakan manusia yang berpotensi, kreatif dan memiliki ide cemerlang sebagai bekal untuk memperoleh masa depan yang lebih baik. Sesuai yang termuat dalam Undang-undang Nomor 20 Tahun 2003 Pasal 1 Ayat 1 tentang Sistem Pendidikan Nasional, yaitu : "Pendidikan adalah usaha sadar dan terencana untuk mewujudkan suasana belajar dan proses pembelajaran agar siswa secara aktif mengembangkan potensi dirinya untuk memiliki kekuatan spiritual keagamaan, pengendalian diri, kepribadian, kecerdasan, akhlak mulia, serta keterampilan yang diperlukan dirinya, bangsa dan negara".

Berhasilnya tujuan pembelajaran ditentukan oleh banyak faktor diantaranya adalah faktor guru dalam melaksanakan proses pembelajaran, karena guru secara langsung dapat mempengaruhi, membina dan meningkatkan kecerdasan serta keterampilan siswa. Oleh karena itu menjadi seorang guru tidak hanya berkaitan dengan mengajar atau mentransfer ilmu kepada siswa, melainkan penggunaan secara integratif berbagai keterampilan dalam menyampaikan pesan kepada peserta didik. Mengingat dalam kegiatan pembelajaran tidak cukup hanya menggunakan satu keterampilan saja, tetapi harus dipadukan dengan keterampilan lainnya.

Menurut Dimyati dan Mudjiono (Syaiful Sagala, 2011) pembelajaran adalah kegiatan guru secara terprogram dalam desain instruksional, untuk membuat belajar secara aktif, yang menekankan pada penyediaan sumber belajar. Guru harus mampu menyelenggarakan proses pembelajaran yang mendidik kepada siswa di dalam kelas. Belajar diartikan sebagai proses membangun makna atau pemahaman terhadap informasi dan/atau pengalaman sehingga terjadi perkembangan pengetahuan, sikap dan keterampilan (Agus Suyatna, 2011). Proses membangun makna tersebut dapat dilakukan sendiri oleh siswa atau bersama orang lain. Proses itu disaring dengan persepsi, pikiran (pengetahuan awal
), dan perasaan siswa. Belajar bukanlah menyerap pengetahuan yang sudah jadi bentukan guru atau memindahkan pengetahuan dari guru kepada siswa.

Matematika merupakan salah satu mata pelajaran pokok yang diajarkan pada setiap jenjang pendidikan termasuk sekolah menengah atas, tetapi tidak sedikit peserta didik yang merasa kesulitan dalam memahami konsep-konsep dalam mata pelajaran matematika. Selama ini terkesan masih banyak guru matematika yang menjelaskan materi hanya dengan ceramah dan jarang mengajak siswa untuk aktif dalam mengembangkan materi sehingga hanya terjadi guru mentransfer ilmu ke siswa namun tanpa adanya timbal balik didalam prosesnya.

Mata pelajaran matematika di tingkat sekolah menengah atas merupakan mata pelajaran yang memiliki cakupan materi yang cukup abstrak dan harus mampu berfikir kritis. Oleh karena itu, diperlukan perencanaan dan pelaksanaan pembelajaran dengan menggunakan model, strategi, dan media pembelajaran yang tepat, sehingga target ketuntasan belajar siswa dapat tercapai. Peran model pembelajaran matematika pun sangat penting dalam kegiatan belajar mengajar, karena dengan model pembelajaran yang tepat akan memudahkan siswa untuk memperoleh pengetahuan yang mendalam tentang materi pelajaran matematika yang diajarkan oleh guru. Akan tetapi, pada kenyataannya penggunaan model pembelajaran matematika oleh guru belum maksimal sesuai dengan apa yang diharapkan. Banyak guru yang belum menggunakan model pembelajaran pada pembelajaran matematika. Pembelajaran matematika cenderung masih berpusat pada guru. Seharusnya model pembelajaran matematika dapat digunakan guru dengan semaksimal mungkin untuk membantu siswa lebih mudah dalam memahami konsep-konsep dalam mata pelajaran matematika.

Hal serupa juga terlihat pada siswa kelas XI IIS MAN Model Jambi, selama proses pembelajaran matematika berlangsung, siswa pasif selama proses pembelajaran dan masih tergantung dari apa 
yang disampaikan guru didepan kelas. Guru yang mengajar terkesan mendominasi pembelajaran dan menjadi satu-satunya penentu arah pembelajaran. Selama proses pembelajaran, siswa sangat tergantung dengan buku teks dan cenderung menghafal rumus-rumus yang tercantum dalam buku teks. Seharusnya siswa dilatih berpikir dan membuat konsep berdasarkan pengamatan dan percobaan yang dilakukan melalui pengalaman berinteraksi dengan lingkungan tanpa memandang sesuai atau tidaknya konsep yang dikemukakan siswa dengan buku pegangan. Akibatnya, hasil belajar matematika yang diperoleh siswa menjadi rendah.

Untuk mengatasi berbagai kelemahan dalam proses pembelajaran maka dalam menyampaikan pelajaran dapat dilakukan dengan menggunakan berbagai macam metode maupun model pembelajaran sehingga mempermudah siswa untuk memahami pembelajaran yang disampaikan. Pada proses pembelajaran perlu adanya kegiatan pembelajaran yang dapat meningkatkan aktivitas dan hasil belajar siswa. Salah satu model pembelajaran yang diharapkan dapat efektif digunakan yaitu penerapan model pembelajaran discovery learning.

Penemuan (discovery) merupakan suatu model pembelajaran yang dikembangkan berdasarkan pandangan konstruktivisme. Menurut Kurniasih \& Sani (2014) discovery learning didefinisikan sebagai proses pembelajaran yang terjadi bila materi pembelajaran tidak disajikan dalam bentuk finalnya, tetapi diharapkan siswa mengorganisasi sendiri. Selanjutnya, Sani (2014) mengungkapkan bahwa discovery adalah menemukan konsep melalui serangkaian data atau informasi yang diperoleh melalui pengamatan atau percobaan.

Menurut Bell dalam Agus Cahyo (2013) beberapa tujuan spesifik dari pembelajaran dengan penemuan, yakni sebagai berikut:

a. Dalam penemuan siswa memiliki kesempatan untuk terlibat secara aktif dalam pembelajaran. Kenyataan menunjukkan bahwa partisipasi banyak siswa dalam pembelajaran menungkatan ketika penemuan digunakan.

b. Melalui pembelajaran dengan penemuan siswa dapat menemukan pola dalam situyasi konkrit maupun abstrak, siswa juga banyak meramalkan (extrapolate) informasi tambahan yang diberikan.

c. Siswa juga belajar merumuskan strategi tanya jawab yang tidak rancuh dan menggunakan tanya jawab untuk memperoleh informasi yang bermanfaat dalam menemukan.

d. Pembelajaran dengan penemuan membantu siswa membentuk cara kerja bersama yang efektif, saling membagi informasi, serta mendengar dan menggunakan ide-ide orang lain.

e. Terdapat beberapa fakta yang menunjukkan bahwa keterampilanketerampilan, konsep-konsep dan prinsip-prinsip yang dipelajari melalui penemuan lebih bermakna.

f. Keterampilan yang dipelajari dalam situasi belajar penemuan dalam beberapa kasus, lebih mudah ditransfer untuk aktifitas baru dan di aplikasikan dalam situasi belajar yang baru.

Berdasarkan uraian di atas, ingin diketahui sejauh mana pengaruh penerapan model pembelajaran discovery learning terhadap hasil belajar matematika. Oleh karena itu, peneliti tertarik untuk mengangkat judul "Pengaruh Model Pembelajaran Discovery Learning terhadap Hasil Belajar Matematika Siswa di MAN Model Kota Jambi". Materi bahasan pada penelitian ini difokuskan pada Pokok Bahasan Matriks yang sedang dipelajari oleh siswa kelas XI IIS tahun pelajaran 2016/2017.

\section{METODE PENELITIAN}

Penelitian ini merupakan penelitian kuantitatif dengan jenis penelitian eksperimen semu (quasi experiment). Populasi pada penelitian ini adalah kelas XI 
IIS yang terdiri dari 5 kelas berjumlah 182 orang. Desain penelitian pada penelitian ini adalah Posttest-Control Grup Design. Sampel dalam penelitian ini adalah siswa kelas XI IIS.2 sebagai kelas eksperimen dan kelas XI IIS.3 sebagai kelas kontrol.

Data dalam penelitian ini diperoleh dari hasil nilai harian Pokok Bahasan Matriks pada siswa kelas XI IIS.2 yang menggunakan model pembelajaran discovery learning (kelas eksperimen) dan siswa kelas XI IIS.3 yang menggunakan model pembelajaran konvensional (kelas kontrol).

Analisis dilakukan untuk menguji apakah ada perbedaan hasil belajar matematika antara yang menggunakan model pembelajaran discovery learning dengan yang menggunakan model pembelajaran konvensional pada siswa kelas XI IIS MAN Model Kota Jambi menggunakan t-test untuk dua sampel besar tidak saling berhubungan. Selanjutnya dilakukan uji lanjut untuk melihat pengaruh model pembelajaran discovery learning terhadap hasil belajar siswa dengan menghitung effect size pada rumus Cohen's berikut.

$$
d_{s}=t_{0} \sqrt{\frac{n_{A}+n_{B}}{n_{A} \cdot n_{B}}}
$$

Keterangan:

$d_{s}=$ besar pengaruh perlakuan yang diberikan

$n_{A}=$ jumlah sampel sebelum menerapkan model pembelajaran PACE

$n_{B}=$ jumlah sampel setelah menerapkan model pembelajaran PACE

$t_{0}=$ hasil uji $t$

\section{HASIL DAN PEMBAHASAN}

Tabel 1. Deskripsi Skor Hasil Belajar Siswa
Perbedaan hasil belajar matematika siswa pada Pokok Bahasan Matriks antara yang menggunakan model discovery learning dalam pembelajaran dengan hasil belajar siswa yang menggunakan model konvensional dalam proses pembelajaran dapat dilihat pada Tabel 1.

Berdasarkan Tabel 1 terlihat bahwa nilai rata-rata hasil belajar matematika siswa yang menggunakan model discovery learning dalam pembelajarannya adalah 77,94 sedangkan nilai rata-rata hasil belajar matematika siswa yang menggunakan model konvensional dalam pembelajarannya adalah 73,53. Dapat dikatakan bahwa nilai rata-rata dari kedua sampel ini berbeda dan jelas nilai rata-rata siswa yang menggunakan model discovery learning dalam pembelajaran lebih besar dibanding nilai rata-rata siswa yang menggunakan model konvensional. Dilihat dari standar deviasi, nilai standar deviasi siswa yang menggunakan model discovery learning adalah 9,07 sedangkan standar deviasi siswa yang menggunakan model konvensional adalah 8,52. Ini menunjukkan bahwa hasil belajar siswa siswa yang menggunakan model konvensional lebih homogen dibandingkan hasil belajar siswa yang menggunakan model discovery learning. Hal ini juga terlihat dari nilai range hasil belajar siswa yang menggunakan model konvensional lebih kecil dibandingkan dengan hasil belajar siswa yang menggunakan model discovery learning.

Untuk melihat signifikansi perbedaan hasil belajar matematika siswa yang menggunakan model discovery learning dengan hasil belajar matematika siswa yang menggunakan model konvensional dalam proses pembelajarannya dilakukan pengujian dengan menggunakan rumus $t$-test.

\begin{tabular}{lcccccc}
\hline Kelas & $\mathrm{N}$ & Terendah & Tertinggi & Range & Mean & Standar Deviasi \\
\hline Eksperimen & 32 & 50 & 90 & 40 & 77,94 & 9,07 \\
\hline Kontrol & 32 & 60 & 90 & 30 & 73,53 & 8,52 \\
\hline
\end{tabular}

Tabel 2. Hasil Uji-t

\begin{tabular}{rccc}
\hline $\mathrm{t}_{\text {hitung }}$ & $\mathrm{df}$ & $\mathrm{t}_{\text {tabel }}$ & Kesimpulan \\
\hline 2,002 & 62 & 1,999 & Tolak $\mathrm{H}_{0}$ \\
\hline
\end{tabular}


Berdasarkan Tabel 2 terlihat bahwa untuk taraf signifikan 5\% diperoleh nilai $\mathrm{t}$ tabel $=1,99$ dengan nilai $\mathrm{t}$ hitung $=2,002$ sehingga 1,99<2,002 dengan demikian $\mathrm{H}_{0}$ ditolak. Artinya diperoleh kesimpulan bahwa terdapat perbedaan hasil belajar matematika siswa antara yang menggunakan model discovery learning dengan hasil belajar matematika siswa yang tidak menggunakan model discovery learning (model konvensional) dalam pembelajarannya.

Selanjutnya dicari nilai efek size untuk melihat besaran pengaruh yang diberikan model pembelajaran terhadap hasil belajar matematika siswa. Dari proses perhitungan diperoleh ds $=0,5005$ yang berada pada kategori sedang dengan persentase $69 \%$. Ini mendeskripsikan bahwa penggunaan model dalam proses pembelajaran matematika di kelas XI IIS MAN Model Kota Jambi memberikan pengaruh sebesar 69\% pada hasil belajar matematika siswa khususnya pada Pokok Bahasan Matriks.

\section{PENUTUP}

Berdasarkan hasil penelitian yang dilakukan pada kelas XI IIS 2 dan XI IIS 3 Madrasah Aliyah Negeri Model Kota Jambi dapat disimpulkan bahwa hasil belajar matematika siswa yang menggunakan model discovery learning lebih baik dari hasil belajar matematika siswa yang tidak menggunakan model discovery learning (model konvensional). Hal ini dapat dibuktikan dengan rata-rata nilai yang diperoleh siswa yang menggunakan model discovery learning adalah 77,94 lebih tinggi daripada nilai rata-rata hasil belajar matematika siswa yang tidak menggunakan model discovery learning adalah 73,53. Dengan demikian, terbukti bahwa hasil belajar matematika siswa yang dalam pembelajarannya menggunakan model discovery learning lebih baik dari hasil belajar matematika siswa yang pembelajarannya tidak menggunakan model discovery learning.

\section{UCAPAN TERIMA KASIH}

Terbitnya tulisan ini tidak terlepas dari bantuan berbagai pihak, untuk itu penulis ucapkan terima kasih kepada UP3M STKIP PGRI Sumatera Barat dan pengelola jurnal Pelangi yang telah memberikan saran dan revisi dalam penulisan artikel ini.

\section{DAFTAR PUSTAKA}

Agus Suyatna. (2011). Model Pembelajaran PAIKEM. Bandar Lampung: Universitas Lampung.

Budiningsih, C Asri. (2005). Belajar dan Pembelajaran. Jakarta: Rineka Cipta

Cahyo, Agus. (2013). Panduan Aplikasi Teori-Teori Belajar Mengajar. Jogjakarta : DIVA Press

Hamalik, Oemar. (2007). Proses Belajar Mengajar, Jakarta:Bumi Aksara

Kurniasih, Imas dan Berlin Sani. (2014). Sukses Mengimplementasikan Kurikulum 2013. Jakarta : Kata Pena

Sagala, Syaiful. (2011). Konsep dan Makna Pembelajaran. Bandung : Alfabeta.

Sardiman, M.A. (2007). Interaksi dan Motivasi Belajar Mengajar. Jakarta: Raja Grafindo Perada.

Sudijono, Anas. (2014). Pengantar Statistik Pendidikan. Jakarta : Rajawali Pers

Winataputra, Udin A, dkk. (2008). Teori Belajar. Jakarta : Universitas Terbuka 